\title{
A Study on Online Shopping and Consumer Behaviour among College Students in Coimbatore District, Tamil Nadu
}

\author{
P. Parameswari ${ }^{1}$ and M. Saravanan ${ }^{2}$ \\ ${ }^{1}$ Research Scholar, ${ }^{2}$ Assistant Professor, \\ ${ }^{1 \& 2}$ School of Communication, Dr. G. R. Damodaran College of Science, Coimbatore, Tamil Nadu, India \\ E-Mail: delsidebi@gmail.com, saraa.m2020@gmail.com
}

\begin{abstract}
The convergence of media technology, most of the people engaged with online buyers' particularly youngsters than other age groups. The arrival of the information age triggered the appearance of a new type of consumer, more demanding and more informed by far more affected by his or her choices. The selective consumer of the $21^{\text {st }}$ century is not easily satisfied and marketers are on a constant watch out to meet his eyes and cope with his needs and preferences. This paper seeks to examine online marketing and consumer behaviour among the college students. The core of the analysis focuses on online purchasing on electronic gadgets and cosmetic products towards the college students. The quantitative method employed to collect data from the respondents and the non-probability category of convenience sampling technique used to collect the data from the students $(\mathrm{N}=100)$. The statistical tool such as percentage, $t$-test, and correlation used to analyze the data. This study finding shows that most of the male respondents' preferred to purchase electronic devices compared to female; the female preferred to purchase cosmetic products than electronic apparatus.

Keywords: Online Marketing, Consumer Behaviour, College Students, Cosmetic
\end{abstract}

\section{INTRODUCTION}

Over the past two decades, a substantial amount of Indian people is engaged with computer and mobile phone via the internet. The utility of the internet increases the person's attitude and behaviors' in several ways, such as learning, business, exchanging information and online purchasing etc. According to (Ma'ruf and Hasrati, 2000) studies found that in the $21^{\text {st }}$ century is considered as an effective electronicera for online technology to do all activities through online such as an e-market, e-business, e-Payment, eEntertainment, e-Ticketing, e-Learning, e-Citizen and eGovernment. According to the report of (internet world statistics, June 2017), there were 462 million claimed internet users in India. Internet as a medium had enlarged the way of purchasing behaviour through online where youth is very eager to buy their products. According to (Sivasankaran, 2017) Online marketing is a way of buying and selling of information, products and services via internet. According to Pavlou (2003), online shopping intention can be defined as a situation which consumer want and intend to do transaction by online.

Kiely (1997) stated that although online shopping has been on the rise, the challenges associated with web based retailing have also increased. Korgaokar and Wolin (1999) studied the demographic variables of consumers' and results show that age, gender, geographic distribution, income, family, and work can affect consumers' online purchasing behaviours. The buying behaviour of an individual control many aspects and these aspects often affect the marketer to identify the needs of the customers in the brand and youth in over demanding. Online trades are now forwarding a large number of orders, such as cosmetics, clothing, electronics, and books, etc. Nowadays, mobile phones played a vital role for online purchases towards people of all ages. Purchase through online is providing a lot of excitement and easier to search the product and its features. The present study aims to attempt an online shopping behavior among college students in Coimbatore.

\section{OBJECTIVES OF THE STUDY}

The following are the objectives of the study based on which the research was conducted.

1. To study demographic and socio-economic strata profile of sample respondents (college students).

2. To explore consumer behaviour towards online marketing and purchasing.

\section{METHODOLOGY}

\section{A. Participants}

This study sample was selected from under graduation and Post-graduation studying students from various colleges in Coimbatore district. The participants ages range from 17 years to 24 years old both male and female.

\section{B. Sampling}

The present study used Non-Probability sampling method of convenience sampling technique has been used to collect data from respondents. The total sample size of the study was 100.

\section{Data Sources}

This study the primary data collected through a structured questionnaire from the respondents and the secondary data include the information obtained from the existing research 
reports, surveys, journals or magazines regarding consumer approach towards online shopping and behaviour.

\section{Measures}

The questionnaire consists of three sections; the first section focuses on demographic information such as gender, age, education, place of staying. The second section focuses on socio - economic status (SES) and respondents' internet usage behaviour. A Third component focuses on participants online consumer purchasing behaviour was assessed using a five-point Likert scale from 1 (strongly disagree) to 5 (strongly agree).

\section{E. Procedure}

The respondents were clarified that participation was voluntary; the data were keep as confidential material. Each participant completed an anonymous survey that gathered the data.

\section{F. Data Analysis}

The study has used descriptive statistics has been used for in the data analysis for the result. The results are summarized in the following.

\section{G. Limitation of the study}

This study was conducted geographical area from the Coimbatore district only (college studying students); the result may not be able to generalize whole Tamil Nadu.

\section{ANALYSIS AND INTERPRETATION OF DATA}

\section{A. Descriptive Statistics}

\section{Demographic Information}

TABLE I PARTICIPANTS DEMOGRAPHIC INFORMATION

\begin{tabular}{|c|c|c|c|c|}
\hline \multirow{2}{*}{ Gender } & $\begin{array}{l}\text { Male } \\
(\mathrm{N})\end{array}$ & percentage & $\begin{array}{c}\text { Female } \\
(\mathrm{N})\end{array}$ & percentage \\
\hline & 37 & $37 \%$ & 63 & $63 \%$ \\
\hline \multirow{2}{*}{ Age } & $17-21$ & percentage & $21-24$ & percentage \\
\hline & 65 & $65 \%$ & 35 & $35 \%$ \\
\hline \multirow{2}{*}{$\begin{array}{l}\text { Place of } \\
\text { Staying }\end{array}$} & City (N) & Urban $(\mathrm{N})$ & $\begin{array}{c}\text { Suburban } \\
(\mathrm{N})\end{array}$ & Rural (N) \\
\hline & 41 & 31 & 12 & 16 \\
\hline \multirow[t]{2}{*}{$\begin{array}{c}\text { Educational } \\
\text { Qualification }\end{array}$} & $\begin{array}{c}\text { UG } \\
\text { Pursuing } \\
(\mathrm{N})\end{array}$ & Percentage & $\begin{array}{c}\text { PG } \\
\text { Pursuing } \\
(\mathrm{N})\end{array}$ & Percentage \\
\hline & 56 & $56 \%$ & 44 & $44 \%$ \\
\hline
\end{tabular}

This study result reveals that the total number of respondents' $37 \%$ was male $(n=37)$ and $63 \%$ were female $(n=63)$; the participants age ranging from $17-21$ were $65 \%$ of respondents and $21-24$ were $35 \%$ of respondents. A total number of participants' 56\% respondents were pursuing under graduation and $44 \%$ was studying a post-graduation program in college. The samples place of residing were $41 \%$ were residing city ( $n=41), 31 \%$ were urban, $12 \%$ were semi-urban and $16 \%$ were rural residing at Coimbatore city and suburban areas (table I).

\section{Socio-Economic Strata - Information}

Table II, indicates that the participants' socio-economic strata (SES), the respondents place of residing reveals that $41 \%$ were city, $31 \%$ urban, $16 \%$ were rural and $12 \%$ were semi-urban; the participants having an electronic device to access the internet the result shown that $77 \%$ of students have mobile phones and $18 \%$ has laptop \& 5\% had a personal computer (PC). This study result indicates that students preferred mobile phone to access the internet than other electronic gadgets. The respondent's family monthly income $8.0 \%$ respondents monthly family income below 10000 rupees, $18.0 \%$ respondents monthly family income ranges between 10001 to 20000 rupees, $15.0 \%$ respondents monthly family income is 20001 to 30000 rupees, $20.0 \%$ respondents monthly family income is 30001 to 40000 rupees, $21.0 \%$ respondents monthly family income is above 50000 rupees. The highest respondents are 21 with above 50000 monthly family incomes.

\section{Participants' Uses and Preferences}

\section{A. What are the Websites do you Visit to Purchase Online?}

The respondents visit websites to purchase on online products, this study result reveals that nearly fifty percentage of the respondents $(\mathrm{N}=45)$ visit to buy the products from the Amazon website and $(\mathrm{N}=35)$ visit flip kart, a considerable percentage of respondents visit the shop clues, eBay and Myntra websites.

\section{B. How Often do you Purchase from Online?}

The above table shows, how often does the respondents purchase from online two-third of the respondents stated that $64 \%$ two months once and $26 \%$ were reported that once in a month and $15 \%$ were once in a week and another $1 \%$ stated that once in a week purchase the products.

C. How Much Time do you spend on the Internet Every Day?

TABLE II FREQUENCY OF BUYING ELECTRONICS AND COSMETICS PRODUCTS THROUGH ONLINE

\begin{tabular}{|l|c|c|c|}
\hline $\begin{array}{c}\text { Buying } \\
\text { electronics } \\
\text { products } \\
\text { through } \\
\text { online }\end{array}$ & Percentage & $\begin{array}{c}\text { Buying cosmetics } \\
\text { products through } \\
\text { online }\end{array}$ & Percentage \\
\hline Frequently & 24 & Frequently & 24 \\
\hline Rarely & 38 & Rarely & 44 \\
\hline Not at all & 38 & Not at all & 32 \\
\hline Total & 100 & Total & 100 \\
\hline
\end{tabular}


A total number of the respondents, nearly $46 \%$ were spending 2-4 hours and 25\% were spending internet on every day more than 5 hours and 16\% were below 2 hrs per day.

The table II shows the $24 \%$ of the respondents' frequently buying electronics products through online and $38 \%$ respondents rarely purchased electronic products. The cosmetics products $68 \%$ of respondents buying frequently and rarely; $32 \%$ of participants, not at all buying cosmetics products through online.

\section{Customers' Online Shopping Behaviour}

The customer online purchasing behaviour was assessed using a 5 Likert scale analyzing 10 questions (items) of customer behaviour factors. These are summarized in the below section.

The above table shows the statement, I am aware of how to buy online with strongly disagree respondents, are 2 (2.0\%), they disagree respondents are 3 (3.0\%), the neutral (can't say) respondents are 15 (15.0\%), agree respondents are 29 (29.0\%), and strongly agree Likert points from the respondents are 51 (51.0\%). I am aware of how to buy online; the respondents are more in the highest level of agreement on Likert scale is strongly agree.

The above table shows the statement, I am a regular online buyer, with strongly disagree respondents, are 5 (5.0\%), I am a regular online buyer, with disagree respondents are 23 (23.0\%), the neutral (can't say) respondents are 32 (32.0\%), I am a regular online buyer, agree respondents are 24 (24.0\%), and strongly agree Likert points from the respondents are 16 (16.0\%). I am a regular online buyer, for this statement neutral (can’t say) respondents are more.

TABLE III I PREFER ONLINE BUYING DUE TO CONVENIE
\begin{tabular}{|l|c|}
\hline $\begin{array}{c}\text { Statement } \\
\text { I prefer online buying } \\
\text { due to convenience }\end{array}$ & Percentage \\
\hline Strongly disagree & 5.0 \\
\hline Disagree & 23.0 \\
\hline Neutral (can't say) & 32.0 \\
\hline Agree & 24.0 \\
\hline Strongly agree & 16.0 \\
\hline Total & 100.0 \\
\hline
\end{tabular}

The above table shows the statement, I prefer online buying due to convenience, with strongly disagreeing respondent, are $1(1.0 \%)$, I prefer online buying due to convenience, with disagree respondents are 12 (12.0\%), the neutral (can't say) respondents are 20 (20.0\%), I prefer online buying due to convenience, agree respondents are 51 (51.0\%), and strongly agree respondents are 16 (16.0\%). I prefer online buying due to convenience, for this statement agrees respondents are more.
TABLE IV I AM COMFORTABLE BUYING ALL MY REQUIREMENTS ONLINE

\begin{tabular}{|l|c|}
\hline $\begin{array}{c}\text { Statement } \\
\text { I am comfortable buying all } \\
\text { my requirements online }\end{array}$ & Percentage \\
\hline Strongly disagree & 11.0 \\
\hline Disagree & 13.0 \\
\hline Neutral (can't say) & 29.0 \\
\hline Agree & 35.0 \\
\hline Strongly agree & 12.0 \\
\hline Total & 100.0 \\
\hline
\end{tabular}

The above table shows the statement, I am comfortable buying all my requirements online, with strongly disagree respondent, are 11 (11.0\%), I am comfortable buying all my requirements online, with disagree respondents are 13 (13.0\%), the neutral (can't say) respondents are 29(29.0\%), I am comfortable buying all my requirements online, agree respondents are 35 (35.0\%), and strongly agree respondents are $12(12.0 \%)$.

TABLE V I FEEL SECURE ABOUT MONEY REFUND ON PURCHASE RETURNS

\begin{tabular}{|l|c|}
\hline $\begin{array}{c}\text { I feel secure about money refund } \\
\text { on purchase returns }\end{array}$ & Percentage \\
\hline Strongly disagree & 3.0 \\
\hline Disagree & 20.0 \\
\hline Neutral (can't say) & 24.0 \\
\hline Agree & 39.0 \\
\hline Strongly agree & 14.0 \\
\hline Total & 100.0 \\
\hline
\end{tabular}

The above table shows the statement, I feel secure about a money refund on purchase returns, with strongly disagree respondents, are $3(3.0 \%)$, with disagreeing respondents are $20(20.0 \%)$, the neutral (can't say) respondents are 24 (24.0\%), agree respondents are 39 (39.0\%), and strongly agree respondents are $14(14.0 \%)$.

TABLE VI I AM SATISFIED WITH THE QUALITY OF PRODUCTS I BUY ONLINE

\begin{tabular}{|l|c|}
\hline $\begin{array}{c}\text { Statement } \\
\text { I am satisfied with the quality of } \\
\text { products I buy online }\end{array}$ & Percentage \\
\hline Strongly disagree & 5.0 \\
\hline Disagree & 9.0 \\
\hline Neutral (can't say) & 40.0 \\
\hline Agree & 36.0 \\
\hline Strongly agree & 10.0 \\
\hline Total & 100.0 \\
\hline
\end{tabular}

The above table shows the statement, I am satisfied with the quality of products I buy online, with strongly disagree respondents, are 5 (5.0\%), with disagreeing respondents are 9 (9.0\%), the neutral (can’t say) respondents are 40 (40.0\%), 
agree respondents are 36 (36.0\%), and strongly agree respondents are $10(10.0 \%)$.

TABLE VII IT IS EASY TO RETURN PRODUCT BOUGHT ONLINE

\begin{tabular}{|l|c|}
\hline \multicolumn{1}{|c|}{$\begin{array}{c}\text { Statement } \\
\text { It is easy to return product } \\
\text { bought online }\end{array}$} & Percentage \\
\hline Strongly disagree & 5.0 \\
\hline Disagree & 9.0 \\
\hline Neutral (can't say) & 40.0 \\
\hline Agree & 36.0 \\
\hline Strongly agree & 10.0 \\
\hline Total & 100.0 \\
\hline
\end{tabular}

The above table shows the statement, It is easy to return product bought online, with strongly disagree respondents, are $14(14.0 \%)$, with disagreeing respondents are 10 (10.0\%), the neutral (can't say) respondents are 21 (21.0\%), agree respondents are 32 (32.0\%), and strongly agree respondents are $23(23.0 \%)$.

TABLE VIII FINDING RIGHT PRODUCT ONLINE IS EASY

\begin{tabular}{|l|c|}
\hline \multicolumn{1}{|c|}{$\begin{array}{c}\text { Statement } \\
\text { Finding right product online is easy }\end{array}$} & Percentage \\
\hline Strongly disagree & 5.0 \\
\hline Disagree & 9.0 \\
\hline Neutral (can't say) & 40.0 \\
\hline Agree & 36.0 \\
\hline Strongly agree & 10.0 \\
\hline Total & 100.0 \\
\hline
\end{tabular}

The above table shows the statement, Finding right product online is easy, with strongly disagree respondents, are 5 (5.0\%), with disagreeing respondents are 9 (9.0\%), the neutral (can't say) respondents are 28 (28.0\%), agree respondents are $40(40.0 \%)$, and strongly agree respondents are $18(18.0 \%)$.

TABLE IX I AM SATISFIED WITH ALL MY ONLINE PURCHASES

\begin{tabular}{|l|c|}
\multicolumn{1}{|c|}{$\begin{array}{c}\text { Statement } \\
\text { I am satisfied with all my online } \\
\text { purchases }\end{array}$} & Percentage \\
\hline Strongly disagree & 2.0 \\
\hline Disagree & 12.0 \\
\hline Neutral (can't say) & 35.0 \\
\hline Agree & 35.0 \\
\hline Strongly agree & 16.0 \\
\hline Total & 100.0 \\
\hline
\end{tabular}

The above table shows the statement, I am satisfied with all my online purchases, with strongly disagree respondents, are $2(2.0 \%)$, with disagreeing respondents are $12(12.0 \%)$, the neutral (can't say) respondents are 35 (35.0\%), agree respondents are 35 (35.0\%), and strongly agree respondents are $16(16.0 \%)$.

TABLE X I RECOMMEND ONLINE BUYING TO EVERYBODY I KNOW

\begin{tabular}{|l|c|}
\hline \multicolumn{1}{|c|}{$\begin{array}{c}\text { Statement } \\
\text { I recommend online buying to } \\
\text { everybody I know }\end{array}$} & Percentage \\
\hline Strongly disagree & 3.0 \\
\hline Disagree & 12.0 \\
\hline Neutral (can't say) & 38.0 \\
\hline Agree & 26.0 \\
\hline Strongly agree & 21.0 \\
\hline Total & 100.0 \\
\hline
\end{tabular}

The above table shows the statement, I recommend online buying to everybody I know, with strongly disagree respondents, are 3 (3.0\%), with disagreeing respondents are $12(12.0 \%)$, the neutral (can't say) respondents are 38 (38.0\%), agree respondents are 26 (26.0\%), and strongly agree respondents are 21 (21.0\%).

\section{SUMMARY OF FINDINGS}

1. This study examined the online marketing and consumer behaviour among college students.

2. This study found that a majority of the respondents were female (63\%) than male (37\%).

3. The respondents educational qualification were $56 \%$ were studying UG programs and 44\% were studying PG programs.

4. More than $70 \%$ of the participants' were residing at Coimbatore city and urban areas;

5. Majority of the respondents (77\%) accessed the internet through mobile phones.

6. Nearly $90 \%$ of the respondents buy the products through online once in a month and two months once only compared to other categories.

7. This study found that $60 \%$ of the respondents spend 25 hours internet every day and 25\% were spending more than 5 hour internet every day.

8. The present study found that the respondents' first preferred online shopping website Amazon and second preference flip kart; followed by e-bay, Myntra, shop clues and jabong.

9. $62 \%$ of the respondents states that they are buying electronic products through online frequently and rarely and similarly (68\%) found that cosmetics products.

\section{FINDINGS RELATED TO ONLINE MARKETING CUSTOMER BEHAVIOUR}

1. $80 \%$ of the respondents agree that they know how to buy online shopping; $40 \%$ of the participants agreed that buying online regular basis and $30 \%$ were disagreeing that buying online regularly.

2. Majority of the respondents $(\mathrm{N}=67)$ reported that online buying is convenience than traditional buying 
behaviour, because of the time saving, compare the products in many websites, features etc.

3. Half of the respondents agree that comfortable online purchasing and satisfied with online marketing purchase; in addition, online marketing fulfilled the all the requirement of the customers.

4. $46 \%$ were agreeing that satisfied with the quality of the product online and $40 \%$ were states that can't say about the online product quality.

5. A total number of the respondents, 53\% were agreed that they feel secure about money transaction and money refund on purchase through online mode; 23\% were disagreed and $24 \%$ were stated that can't say about money refund and purchasing on return.

6. Nearly $46 \%$ were agreed that easy to return a product bought online; $40 \%$ were states that can't say and $14 \%$ was dis-agreeing that online product easy to return.

7. Three fifth of the respondents (58\%) were agreeing that finding right product online is easy and $28 \%$ were reported that can't say and others are disagreeing.

8. Out of 100 respondents, $46 \%$ of the respondents agreed that recommend online buying to everybody I know and $38 \%$ were stated that can't say followed by $15 \%$ were disagree to recommend online buying to others.

\section{CONCLUSION}

This study concludes that the college students preferred to buy online products such as electronic and cosmetics than other categories. An online shopping is convenience compared to the traditional method of buying behavior. In addition, online marketing fulfilled the all the requirement of the customers and they feel secure money transaction and money refund on purchase through online.

\section{REFERENCES}

[1] Kiely T. (1997). The internet: fear and shopping in cyberspace. Harv Bus Rev, 75, 13-14.

[2] Korgaokar and Wolin, L. D. (1999). A Multivariate analysis of web usage. J Adv Res, 39, 53-68.

[3] Ma'ruf, J. J. (2005). Penerapan Technology Accceptance Model (TAM) Dalam Meramalkan Niat Adopsi Teknology: Suatu Penemuan Empiris. Jurnal Manajemendan Bisnis, 7(1), 25-46.

[4] Paul A.Pavlou. (2003). Consumer Acceptance of Electronic Commerce: Integrating Trust and Risk with the Technology Acceptance Model.

[5] Sivasankaran. S. (2017). Digital Marketing and Its Impact on Buying Behaviour of Youth Special Reference to Kanyakumari District. International Journal of Research in Management \& Business Studies, 4(3), 35-38.

[6] Retrieved from www.Internet world statistics.com. 